\title{
ANALYSIS OF FACTORS INFLUENCING MILLENNIAL'S TECHNOLOGY ACCEPTANCE OF CHATBOT IN THE BANKING INDUSTRY IN INDONESIA
}

\author{
Richad Richad, Vivensius Vivensius, Sfenrianto Sfenrianto and Emil R. Kaburuan \\ Department of Information Systems Management \\ BINUS Graduate Program - Master of Information Systems Management \\ Bina Nusantara University, Jakarta, Indonesia, 11480.
}

\begin{abstract}
The purpose of this research is to analyze factors that influence millennial's technology acceptance of chatbot in the banking industry in Indonesia. In this quantitative research, innovativeness is the exogenous variable, while the endogenous variables are perceived usefulness, perceived ease of use, and attitude towards using and behavioral intention. This research used primary data gathered from distributed questionnaires, directly from the millennial people in Indonesia. Using simple random sampling technique to total sample of 400 people out of the total population of 90 million people. Statistical analysis in this research is conducted using Partial Least Square Structural Equation Model (PLS-SEM). The result shows that innovativeness, perceived usefulness, perceived ease of use and attitude towards using the chatbot affected behavioral intention.
\end{abstract}

Keywords: Chatbot, Banking Industry, Millennial, Technology Acceptance Model (TAM), Partial Least Square-Structural Equation Model (PLS-SEM).

Cite this Article: Richad Richad, Vivensius Vivensius, Sfenrianto Sfenrianto and Emil R. Kaburuan, Analysis of Factors Influencing Millennial's Technology Acceptance of Chatbot in the Banking Industry in Indonesia, International Journal of Management, 10 (3), 2019, pp. 107 - 118,

http://iaeme.com/Home/issue/IJM?Volume=10\&Issue=3

\section{INTRODUCTION}

The technological developments have touched every aspect of human life from business, education, health, to financial services for the community. One form of technological development in the field of financial services is the emergence of chatbot applications that are part of artificial intelligence and are available for various platforms such as LINE, Facebook Messenger and Google Assistant. The presence of several chatbots in the banking industry in 
Indonesia such as Vira, Sabrina and Mita is also due to the existence of several supporting technologies such as the development of the internet and smartphones in Indonesia.

Among on data from wearesocial.com specifically in Indonesia itself as of January 2018 internet usage has touched the figure of $50 \%$ or half of the total population of 265.4 million. This shows that most people in Indonesia have used internet technology, where several activities carried out by the people in Indonesia are to access social media, online shopping, and browsing. Likewise, with data obtained from statista.com regarding the development of smartphone use in Indonesia which has reached $26.26 \%$ of the total population in Indonesia in 2018.

There are many organizations, including banks, use chatbot applications that are available in various social media platforms, such as LINE and Facebook Messenger. With the chatbot, banks can provide customer services for 24 hours per day in a week, can be accessed anywhere, and can also provide efficiency in customer service activities. Chatbot can provide a quick response to questions from customers, to provide a good customer experience.

Millennials with a population of 90 million, or around $34.45 \%$ of Indonesia's total population constitute a large market share for the banking industry. Based on the Indonesia Millennial Report 2019 report conducted by the IDN Research Institute, the results of the research show that $94.4 \%$ of millennials in Indonesia have been connected to the internet. The internet is a major need for millennials. And most or about $98.2 \%$ of activities carried out on the internet are accessed via smartphones. With the chatbot, millennial customers are now able to find out various kinds of banking products and services quickly, such as promotion information, exchange rates, the nearest ATM location, and can also register for credit cards and mortgages. In addition, millennial customers can also check balances, check accounts, credit card information, and other administrative services.

The purpose of this study was to determine the factors of acceptance of chatbot technology in the banking industry in Indonesia, especially for the millennial generation. Therefore, an appropriate model is needed to be able to know the factors of acceptance of the technology, so we used the Technology Acceptance Model (TAM), modified by Davis in 1989.

\section{LITERATURE REVIEW}

\subsection{Chatbot}

Chatbot (also known as a talkbot, chatterbox, Bot, Instant Messaging-bot or Artificial Conversational Entity) is a computer program that mimics human conversations in its natural format including text or spoken language using artificial intelligence techniques such as Natural Language Processing (NLP), image and video processing, and audio analysis [4].

Chatbot enables its users to communicate with it to form an intelligent communication [9, 11] along with providing results or completed tasks as the user instructed it to [12]. The implementation of Chatbot has existed for years, but in various forms - it gained popularity ever since the release of Apple's Siri and Alexa for Amazon [11].

The advancement of Chatbot technology development, mainly in programming language, drives the performance of Chatbot known nowadays [19]. While it is used to performed tasks and answers questions, Chatbot are now capable of doing the business itself [16]. Even so, Chatbot are still facing issues regarding securities and trusts [8]. It is still vulnerable to web attacks and needs serious attention in development of its security systems. Regardless of it, Chatbot are still proven to be in the leading position of business enabler, due to having various utilities and little to none compatibility issues, it is the future of business assistance tool. [15, $25,27]$. 


\subsection{Millennials}

Individuals who are born in between year 1980 and 2000 are called Millennials, due to having been born close to the next millennium (year 2000) and were raised in modern age where technology have been further advanced. The millennials are easily identified by having high acceptance rate on new technologies, and even greater acceptance on capturing new values of non-traditional families and customs [24].

\subsection{Banking Industry}

As an intermediary for financial transactions, a bank is doing its business processes primarily on offering savings and lending money to potential borrowers in order to develop economy within organizations. Advancement of technology enables a bank to penetrate market on larger, wider scale by further enhancing its presence and it is obligated to provide fast, secure and ubiquitous services (as in financial services) to customers, in order to create profit, with the implementation of various business objectives and strategies [1].

Compilations of bank are known as banking industry; this is to segregate the purposes of the banking itself - from financial support, savings, and insurance, banking industry are moving toward to provide beneficial supports for people [7, 21, 23].

\subsection{Technology Acceptance Model (TAM)}

TAM helps researchers determine which factors dominates the acceptance rate within a system, or subsystems [17]. It was developed by researchers to achieve its main purpose-determining the acceptance rate of a technology by individuals or organizations and its usage; thus called behavioral intention, which is determined from two subsets; the perceived usefulness and perceived ease of use. Perceived usefulness depends on how a technology enhances one's daily routines by measuring the improvement of the performance of oneself, whilst perceived ease of use defined as the effortless attempt in using the technology to do the daily routines [26].

\subsection{Partial Least Square - Structural Equation Model (PLS-SEM)}

PLS-SEM differs from general, factor-based SEM. In fact, PLS-SEM does calculation on several values of latent variables in research with specified algorithm. Different from factorbased SEM, PLS-SEM explicitly calculates case values for the latent variables as part of the algorithm, with unobservable variables defines the estimate for exact linear combinations from indicators within it, empirically. It is then resulting composite results for most of the exogenous constructs' indicators variant-which is useful to predict the endogenous ones. It is using the composite to determine constructs in its path model, as an estimation of the conceptual variable of the research [22].

\subsection{Previous Study}

Based on the empirical study determination that in the last time of the last 10 years, accumulatively there are 5 international publications that discuss about the technology acceptance in several applications that can be seen on Table 1.

Table 1 Previous Study on Significant Factors

\begin{tabular}{|l|l|l|l|l|l|}
\hline Reference & {$[2]$} & {$[3]$} & {$[6]$} & {$[13]$} & {$[20]$} \\
\hline Perceived Usefulness & $\checkmark$ & $\checkmark$ & $\checkmark$ & $\checkmark$ & $\checkmark$ \\
\hline Perceived Ease of Use & $\checkmark$ & $\checkmark$ & $\checkmark$ & $\checkmark$ & $\checkmark$ \\
\hline
\end{tabular}




\begin{tabular}{|l|l|l|l|l|l|}
\hline Attitude Towards Using & $\checkmark$ & $\checkmark$ & $\checkmark$ & & \\
\hline Behavioral Intention & $\checkmark$ & $\checkmark$ & $\checkmark$ & & $\checkmark$ \\
\hline Innovativeness & & $\checkmark$ & & & \\
\hline
\end{tabular}

\section{THEORETICAL ANALYSIS}

\subsection{Research Model}

This research aims to examine the millennial's technology acceptance of chatbot in banking industry in Indonesia with TAM, consisting of external variables, perceived usefulness, perceived ease of use, attitude towards of using and behavioral intention. External variable that will be discussed in this paper is Innovativeness of chatbot. The variable indicators in this paper can be seen in Table 2.

Table 2 Variable Indicators

\begin{tabular}{|c|c|c|}
\hline Variable & Variable Indicator & References \\
\hline \multirow{4}{*}{$\begin{array}{l}\text { Innovativeness } \\
\quad \text { (IV) }\end{array}$} & IV1: New innovations in chatbot application & [5] \\
\hline & IV2: Innovation can increase convenience using chatbot & \\
\hline & IV3: Innovation can increase customer desires using chatbot & \\
\hline & IV4: In general, customer is ready to accept new ideas & \\
\hline \multirow{4}{*}{$\begin{array}{c}\text { Perceived } \\
\text { Usefulness (PU) }\end{array}$} & $\begin{array}{l}\text { PU1: Chatbot can improve performance of getting information and } \\
\text { doing transactions. }\end{array}$ & {$[10,18]$} \\
\hline & $\begin{array}{l}\text { PU2: By using chatbot, customer can get information and do } \\
\text { transaction faster }\end{array}$ & \\
\hline & PU3: Chatbot can improve productivity of customer transactions & \\
\hline & $\begin{array}{l}\text { PU4: Chatbot can improve the quality of getting information and } \\
\text { doing transactions }\end{array}$ & \\
\hline \multirow{4}{*}{$\begin{array}{l}\text { Perceived Ease } \\
\text { of Use (PEOU) }\end{array}$} & PEOU1: Chatbot is easy to learn & {$[18,25]$} \\
\hline & PEOU2: Customer can use chatbot without help from anyone & \\
\hline & $\begin{array}{l}\text { PEOU3: Interaction between customer and chatbot is clear and } \\
\text { easy to understand }\end{array}$ & \\
\hline & PEOU4: Customer need much effort to use chatbot & \\
\hline \multirow{3}{*}{$\begin{array}{c}\text { Attitude } \\
\text { Towards Using } \\
\text { (AT) }\end{array}$} & $\begin{array}{l}\text { AT1: Getting information and transaction in chatbot is not a good } \\
\text { idea }\end{array}$ & [18] \\
\hline & AT2: Customer is willing to use chatbot if it is affordable & \\
\hline & $\begin{array}{c}\text { AT3: Customer like the idea of using chatbot to facilitate getting } \\
\text { information and doing transactions }\end{array}$ & \\
\hline
\end{tabular}


Analysis of Factors Influencing Millennial's Technology Acceptance of Chatbot in the Banking Industry in Indonesia

\begin{tabular}{|c|c|c|}
\hline & AT4: Using chatbot can be a good experience & \\
\hline \multirow{3}{*}{$\begin{array}{c}\text { Behavioral } \\
\text { Intention (BI) }\end{array}$} & BI1: Customer choose to use chatbot for getting information and \\
doing transaction & BI2: There is possibility that Customer will use chatbot & \\
\cline { 2 - 3 } & BI3: Customer will not recommend anyone to use chatbot & \\
\cline { 2 - 3 } & BI4: Customer expect to always be able to use chatbot & \\
\hline
\end{tabular}

The research model used in this article is a modification to fit the scope of the research, which is derived from modified version of TAM developed by Davis, Bogozzi and Warshaw in 1989 [14]. This modified version firstly defined in order to explain various behavior of users on using a technology, where it is believed that an external variable is influencing the acceptance of the users. It is illustrated in Figure 1.

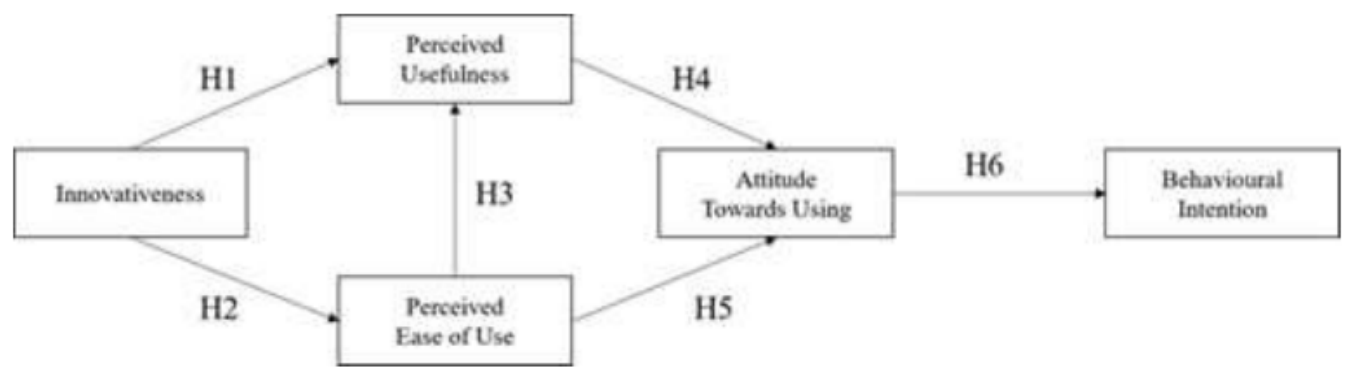

Figure 1. Research Model ${ }^{\text {a }}$

a Adapted from a research article by Lai, P. C. (2017) [14]

\subsection{Analysis Model}

The process of analysis is carried out on the results of the stages of data collection with questionnaire instruments. Data analysis was supported using SmartPLS version 2 software. Scenario analysis was carried out using the Structural Equation Model Partial Least Squares (SEM-PLS) method. PLS method consists of 2 models, namely measurement (outer model) and structural (inner model).

\section{RESULTS AND DISCUSSIONS}

\subsection{Results}

Data type used in this research is primary data that is obtained by collecting questionnaire directly from millennials in Indonesia with a total population of 90 million. Sampling method that is used in this research is simple random sampling and Slovin's formula to determine sample size, which is 400 respondents. Statistical analysis that is used in this research is PLSSEM.

\subsubsection{The Assessment of Measurement Model}

The measurement model used in this research consist of six constructs, Innovativeness (IV) as external variable, Perceived Usefulness (PU), Perceived Ease of Use (PEOU), Attitude towards Using (AT) and Behavioural Intention (BI). Assessment of the reflective measurement model requires to examine the validity and reliability for every latent variable in the model. First, to 
evaluate the convergent validity of the measurement model, outer loading, composite reliability (CR), and average variance extracted (AVE) were assessed.

In evaluating reliability of a model, calculating the loading score of each indicator associated with a latent variable and comparing this calculation with the threshold score is needed. In general, outer loading scores that are above 0.70 indicate reliability. The score of each outer loading in this research (0.70-0.87) is above the threshold score of 0.70 .

The convergent validity can be examined by the score of Average Variances Extracted (AVE), where it needs to exceed 0.5 to indicate adequate convergent validity. All constructs used in this research exceeded the threshold score. The internal consistency of all the constructs in the model was examined by employing Cronbach's $\alpha$ and composite reliability (CR). The threshold score used is 0.70 . The Cronbach's $\alpha$ score and CR of the model were determined to exceed the recommended score of 0.70. Thus, the measurement model has acceptable reliability. Table 3 shows outer loading, Cronbach's $\alpha$, CR and AVE for all constructs.

Table 3 Assessment Result Of The Measurement Model

\begin{tabular}{|c|c|c|c|c|c|}
\hline Construct & Items & $\begin{array}{l}\text { Outer } \\
\text { Loading }\end{array}$ & $\begin{array}{l}\text { Composite } \\
\text { Reliability }\end{array}$ & AVE & $\begin{array}{l}\text { Cronbach's } \\
\alpha\end{array}$ \\
\hline & Innovativeness & & 0.78 & 0.51 & 0.71 \\
\hline IV1 & New innovations in chatbot application & 0.71 & & & \\
\hline IV2 & $\begin{array}{l}\text { Innovation can increase convenience } \\
\text { using chatbot }\end{array}$ & 0.85 & & & \\
\hline IV3 & $\begin{array}{l}\text { Innovation can increase customer desires } \\
\text { using chatbot }\end{array}$ & 0.86 & & & \\
\hline \multirow[t]{2}{*}{ IV4 } & $\begin{array}{l}\text { In general, customer is ready to accept } \\
\text { new ideas }\end{array}$ & 0.75 & & & \\
\hline & Perceived Usefulness & & 0.77 & 0.57 & 0.70 \\
\hline PU1 & $\begin{array}{l}\text { Chatbot can improve performance of } \\
\text { getting information and doing }\end{array}$ & 0.70 & & & \\
\hline PU2 & $\begin{array}{l}\text { By using chatbot, customer can get } \\
\text { information and do transaction faster }\end{array}$ & 0.85 & & & \\
\hline PU3 & $\begin{array}{l}\text { Chatbot can improve productivity of } \\
\text { customer transactions }\end{array}$ & 0.70 & & & \\
\hline \multirow[t]{2}{*}{ PU4 } & $\begin{array}{l}\text { Chatbot can improve the quality of } \\
\text { getting information and doing }\end{array}$ & 0.72 & & & \\
\hline & Perceived Ease of Use & & 0.85 & 0.59 & 0.76 \\
\hline PEOU1 & Chatbot is easy to learn & 0.82 & & & \\
\hline PEOU2 & $\begin{array}{l}\text { Customer can use chatbot without help } \\
\text { from anyone }\end{array}$ & 0.78 & & & \\
\hline PEOU3 & $\begin{array}{l}\text { Interaction between customer and chatbot } \\
\text { is clear and easy to understand }\end{array}$ & 0.79 & & & \\
\hline PEOU4 & $\begin{array}{l}\text { Customer need much effort to use } \\
\text { chatbot }\end{array}$ & 0.76 & & & \\
\hline
\end{tabular}


Analysis of Factors Influencing Millennial's Technology Acceptance of Chatbot in the Banking Industry in Indonesia

\begin{tabular}{|l|l|l|l|l|l|}
\hline & Attitude Towards Using & & 0.84 & 0.58 & 0.74 \\
\hline AT1 & $\begin{array}{l}\text { Getting information and transaction in } \\
\text { chatbot is not good idea }\end{array}$ & 0.78 & & & \\
\hline AT2 & $\begin{array}{l}\text { Customer is willing to use chatbot if } \\
\text { affordable }\end{array}$ & 0.85 & & & \\
\hline AT3 & $\begin{array}{l}\text { Customer like the idea of using chatbot } \\
\text { to facilitate getting information and }\end{array}$ & 0.84 & & & \\
\hline AT4 & Using chatbot can be a good experience & 0.79 & 0.55 & 0.72 \\
\hline BI1 & $\begin{array}{l}\text { Customer choose to use chatbot for } \\
\text { getting information and doing transaction }\end{array}$ & 0.87 & & & \\
\hline BI2 & $\begin{array}{l}\text { There is possibility that Customer will } \\
\text { use chatbot }\end{array}$ & 0.79 & & & \\
\hline BI3 & $\begin{array}{l}\text { Customer will not recommend anyone to } \\
\text { use chatbot }\end{array}$ & 0.76 & & & \\
\hline BI4 & $\begin{array}{l}\text { Customer expect to always be able to use } \\
\text { chatbot }\end{array}$ & 0.79 & & & \\
\hline
\end{tabular}

One of the most common methods for examining discriminant validity is the Fornell Larcker criterion. If a latent variable has more variance than the indicator variables, it is shared with other constructs in the same model, then a discriminant validity is established. Table 4 shows that the cross-loading score of each construct is larger than its corresponding correlation coefficients pointing towards adequate discriminant validity.

Table 4 Discriminant Validity

\begin{tabular}{|c|c|c|c|c|c|}
\hline Construct & AT & BI & IV & PEOU & PU \\
\hline AT 1 & $\mathbf{0 . 4 8 9 6 4 2}$ & 0.401301 & 0.255072 & 0.262867 & 0.225331 \\
\hline AT 2 & $\mathbf{0 . 8 5 5 0 2 6}$ & 0.658730 & 0.341741 & 0.350247 & 0.429058 \\
\hline AT 3 & $\mathbf{0 . 8 4 1 8 4 3}$ & 0.630868 & 0.435162 & 0.303814 & 0.460368 \\
\hline AT 4 & $\mathbf{0 . 7 9 4 4 8 6}$ & 0.614683 & 0.410812 & 0.227994 & 0.326014 \\
\hline BI1 & 0.718578 & $\mathbf{0 . 8 7 0 7 9 0}$ & 0.474339 & 0.468067 & 0.480192 \\
\hline BI2 & 0.619690 & $\mathbf{0 . 7 9 9 4 9 5}$ & 0.358543 & 0.288143 & 0.387301 \\
\hline BI3 & 0.431162 & $\mathbf{0 . 5 6 6 9 1 2}$ & 0.290886 & 0.300086 & 0.302178 \\
\hline BI4 & 0.461569 & $\mathbf{0 . 6 9 6 6 3 9}$ & 0.452868 & 0.316980 & 0.481617 \\
\hline IV1 & 0.448370 & 0.400372 & $\mathbf{0 . 7 1 6 6 5 4}$ & 0.301125 & 0.396634 \\
\hline IV2 & 0.310918 & 0.358667 & $\mathbf{0 . 8 5 8 3 4 6}$ & 0.399123 & 0.484138 \\
\hline IV3 & 0.316809 & 0.404435 & $\mathbf{0 . 8 5 5 5 4 6}$ & 0.396798 & 0.499713 \\
\hline IV4 & 0.348226 & 0.403352 & $\mathbf{0 . 2 5 0 3 0 5}$ & 0.216198 & 0.226139 \\
\hline PEOU 1 & 0.276437 & 0.447141 & 0.376450 & $\mathbf{0 . 8 2 3 6 6 7}$ & 0.634624 \\
\hline PEOU 2 & 0.271534 & 0.374796 & 0.299090 & $\mathbf{0 . 7 8 2 8 4 3}$ & 0.414240 \\
\hline PEOU 3 & 0.383693 & 0.363932 & 0.485476 & $\mathbf{0 . 7 8 7 6 5 4}$ & 0.472885 \\
\hline
\end{tabular}




\begin{tabular}{|c|l|l|l|l|l|}
\hline PEOU 4 & 0.199645 & 0.221852 & 0.254675 & $\mathbf{0 . 6 6 2 3 0 7}$ & 0.447453 \\
\hline PU 1 & 0.220688 & 0.304478 & 0.417136 & 0.430329 & $\mathbf{0 . 7 0 4 0 7 8}$ \\
\hline PU 2 & 0.402068 & 0.493636 & 0.465063 & 0.539714 & $\mathbf{0 . 8 5 4 0 1 6}$ \\
\hline PU 3 & 0.341931 & 0.301703 & 0.228531 & 0.254571 & $\mathbf{0 . 4 0 0 3 4 3}$ \\
\hline PU 4 & 0.372061 & 0.401314 & 0.462532 & 0.514806 & $\mathbf{0 . 7 2 4 9 1 2}$ \\
\hline & & & & & \\
\hline
\end{tabular}

\subsubsection{Evaluation of Structural Model}

The structural model was examined to test the hypotheses that are proposed for conceptual modelling in this research. Like the CB-SEM, the PLS-SEM approach utilizing SmartPLS software does not provide a conventional assessment of the overall model match. Thus, basic measures such as R Square, Original Sample and t-statistics along with the predictive relevance $\left(\mathrm{Q}^{2}\right)$ and effect size $\left(\mathrm{f}^{2}\right)$ measurements and the bootstrapping process with 400 samples, were examined to evaluate the structural model, with the corrected R Square score of all constructs, Goodness of fit index was calculated. This criterion is defined by the geometric mean of the average communality and the model's average $\mathrm{R}$ square score, reported the following cut-off score for assessing the results of the Goodness of fit index analysis: GoF small $=0.1$; GoF medium $=0.25$; GoF large $=0.36$.

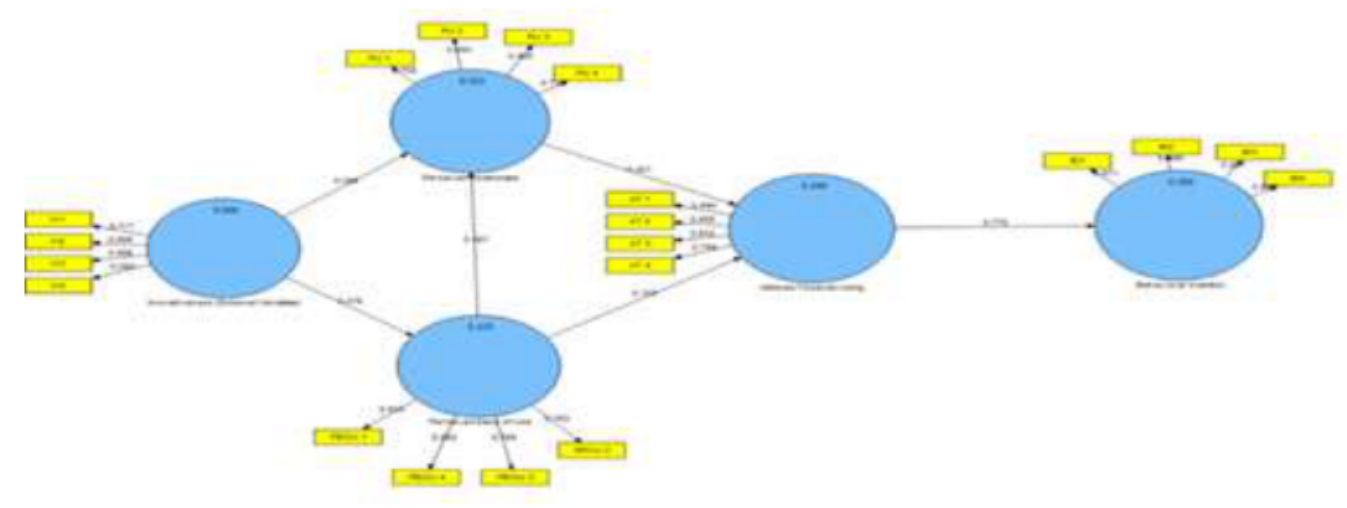

Figure 2. Structural Result Of The Proposed Model

As shown in Table 5, the 0.47 GoF score for the structural model indicates very good global model fit. However, GoF does not represent a true global fit measure, the corrected R Square score and t-statistics of the structural model are analyzed in Figure 2. Primary criterion for inner model assessment is the coefficient of determination ( $\mathrm{R}$ Square), which represents the amount of explained variance of each endogenous latent variable. Innovativeness explains $23 \%$ of perceived ease of used. Innovativeness and perceived ease of use explain $52 \%$ perceived usefulness. Perceived usefulness and perceived ease of use explain $24 \%$ attitude towards using, and attitude towards using explain $59 \%$ behavioral intention.

Table 5 Goodness of Fit Index

\begin{tabular}{|c|c|c|c|}
\hline Construct & AVE & Calculation & R Square $\left(\mathrm{R}^{2}\right)$ \\
\hline Innovations (IV) & 0.51 & & - \\
\hline Perceived Usefulness (PU) & 0.57 & & 0.52 \\
\hline Perceived Ease of Use (PEOU) & 0.59 & & 0.23 \\
\hline
\end{tabular}


Analysis of Factors Influencing Millennial's Technology Acceptance of Chatbot in the Banking Industry in Indonesia

\begin{tabular}{|c|c|c|c|}
\hline Attitude Towards Using (AT) & 0.58 & & 0.24 \\
\hline Behavioral Intention (BI) & 0.55 & & 0.59 \\
\hline Average Score & 0.56 & & 0.40 \\
\hline AVE * R Square & & 0.22 & \\
\hline GoF $=\sqrt{ }($ AVE*R Square) & & 0.47 & \\
\hline
\end{tabular}

Examining $\mathrm{Q}^{2}, \mathrm{f}^{2}$ and multicollinearity in addition to $\mathrm{R}$ Square when evaluating the reflective inner model is necessary. Researchers can evaluate the effect size of the predictor constructs using Cohen's $\mathrm{f}^{2}$. The effect size is computed along with the increase in R Square, which is relative to the proportion of variance that remains unexplained in the endogenous latent variable. The following equation is used in the calculation of the $\mathrm{f}^{2} . \mathrm{f}^{2}$ scores of $0.35,0.15$ and 0.02 are considered large, medium, and small, respectively. In this study, behavioral intentions are predicted attitudes towards using chatbot. Therefore, relative effect sizes $\left(\mathrm{f}^{2}\right)$ of the predicting (exogenous) constructs were calculated and are shown in Table 6. As can be seen from the result of GOF Index in Table 6, attitude towards using had large effects on behavioral intentions.

In addition to $\mathrm{f}^{2}$, the predictive sample reuse technique $\left(\mathrm{Q}^{2}\right)$ could be used effectively as a criterion for predictive relevance. Based on blindfolding procedure, $\mathrm{Q}^{2}$ evaluates the predictive validity of a complex model by omitting data for a given block of indicators and then predicts the omitted part based on the calculated parameters. Researchers can use the cross-validated redundancy as a measure of $\mathrm{Q}^{2}$ since it includes the key element of the path model and the structural model to predict eliminated data points. Thus, for this research, $\mathrm{Q}^{2}$ was obtained using cross-validated redundancy procedures. If $\mathrm{Q}^{2}>0$, then, the model is viewed as having predictive relevance. As shown in Table 6, $\mathrm{Q}^{2}$ for perceived usefulness, perceived ease of use, attitudes towards using, and behavioral intentions are $0.22,0.12,0.12$, and 0.31 respectively, which means they are all indicating acceptable predictive relevance for this research.

Table 6 Predictive Relevance $\left(\mathrm{Q}^{2}\right)$ And Effect Size $\left(\mathrm{f}^{2}\right)$

\begin{tabular}{|c|c|c|}
\hline Construct & Predictive Relevance $\left(\mathrm{Q}^{2}\right)$ & Effect Size $\left(\mathrm{f}^{2}\right)-$ Behavioral Intention \\
\hline Innovativeness (IV) & - & - \\
\hline Perceived Usefulness (PU) & 0.227322 & - \\
\hline Perceived Ease of Use (PEOU) & 0.123793 & - \\
\hline Attitude Towards Using (AT) & 0.122302 & 0.770127 \\
\hline Behavioral Intention (BI) & 0.311781 & - \\
\hline
\end{tabular}

After estimating the structural model, the complete results are summarized in Table 7 . When examined the relationships, Innovativeness positively and significantly affected perceived usefulness $(\mathrm{O}=0.46$, which is $>0.1$ and T-Statistics $=4.67$, which is $>1.96)$. Innovativeness positively and significantly affected perceived ease of use $(\mathrm{O}=0.37$, which is $>0.1$ and $\mathrm{T}$ Statistics $=5.06$, which is $>1.96$ ). Perceived ease of use positively and significantly affected perceived usefulness $(\mathrm{O}=0.55$, which is $>0.1$ and T-Statistics $=5.86$, which is $>1.96)$. Perceived usefulness positively and significantly affected attitude towards using $(\mathrm{O}=0.38$, which is $>0.1$ and T-Statistics $=3.19$, which is $>1.96)$. Perceived ease of use positively and significantly affected attitude towards using $(\mathrm{O}=0.109$, which is $>0.1$ and T-Statistics $=4.86$, which is $>1.96)$. Attitude towards using significantly affected behavioral intention $(\mathrm{O}=0.79$, which is $>0.1$ and T-Statistics $=22.31$, which is $>1.96$ ). 
Table 7 Result Of The Structural Model

\begin{tabular}{|c|c|c|c|c|}
\hline Hypothesis & Construct & Original Sample (O) & T - Statistics & Decision \\
\hline H1 & IV $\rightarrow$ PU & 0.326492 & 4.681581 & Supported \\
\hline H2 & IV $\rightarrow$ PEOU & 0.373251 & 5.068954 & Supported \\
\hline H3 & PEOU $\rightarrow$ PU & 0.558378 & 5.863173 & Supported \\
\hline H4 & PU $\rightarrow$ AT & 0.386073 & 3.196994 & Supported \\
\hline H5 & PEOU $\rightarrow$ AT & 0.109301 & 4.860479 & Supported \\
\hline H6 & AT $\rightarrow$ BI & 0.798120 & 22.318477 & Supported \\
\hline
\end{tabular}

\subsection{Discussions}

The results show that the score of R Square in Table 5 shows the influence of exogenous latent variables on endogenous latent variables for the research, which are 0.52 for perceived usefulness (PU), 0.23 for perceived ease of use (PEOU), 0.24 for attitude towards using (AT), and 0.59 for behavioural intention (BI). Furthermore, from the test results on the score of the effect size $\left(\mathrm{f}^{2}\right)$ in Table 6 , there is a significant effect of the attitude towards using (AT) to behavioural intention $(\mathrm{BI})$, which is 0.77 . In addition to effect size test $\left(\mathrm{f}^{2}\right)$ score, the predictive relevance score $\left(\mathrm{Q}^{2}\right)$ is also done to show that the model has predictive relevance for certain endogenous constructs. As a result, all scores of endogenous variables meet the standard set, which is greater than 0 .

Every hypotheses in this research is proven to be in positive results with all $\mathrm{O}>0.1$ and $\mathrm{T}$ Statistics > 1.96; IV significantly and positively affected PEOU and PU $(\mathrm{O}=0.37$ with TStatistics $=5.06$, and $\mathrm{O}=0.46$ with T-Statistics $=4.67$, respectively), PEOU significantly and positively affected $\mathrm{PU}$ with $\mathrm{O}=0.55$ and $\mathrm{T}$-Statistics $=5.86$ where AT has been significantly and positively affected by PEOU and $\mathrm{PU}(\mathrm{O}=0.109$ with $\mathrm{T}$-Statistics $=4.86$, and $\mathrm{O}=0.38$ with T-Statistics $=3.19$, respectively). Lastly, AT significantly and positively affected BI with $\mathrm{O}=$ 0.79 and $\mathrm{T}$-Statistics $=22.31$.

\section{CONCLUSIONS}

The result of this research shows that factors in this research model has positive impacts on millennial Indonesians upon accepting Chatbot as a technology for banking industry. Innovation as the exogenous variable drives those millennial to accept Chatbot to help them do financial transactions with a bank; given from positive impacts from its usefulness and the ease of use. This severely impact their attitudes towards chatbot - which is developed by having various experiences that they may receive upon using it, and ended up prioritizing the use of it, or even as far as recommending it to others.

\section{REFERENCES}

[1] Aithal, P. S, Ideal Banking Concept and Characteristics. International Research Journal of Management, IT and Social Sciences (IRJMIS), 3(11), 2016, pp 46-55.

[2] Alharbi, S., \& Drew, S, Using the technology acceptance model in understanding academics' behavioural intention to use learning management systems. International Journal of Advanced Computer Science and Applications, 5(1), 2014, pp 143-155.

[3] Ashraf, A. R., Thongpapanl, N. (Tek), \& Auh, S, the Application of the Technology Acceptance Model under Different Cultural Contexts: The Case of Online Shopping Adoption. Journal of International Marketing, 22(3), 2014, 68-93. 
Analysis of Factors Influencing Millennial's Technology Acceptance of Chatbot in the Banking Industry in Indonesia

[4] Bala, K., Kumar, M., Hulawale, S., \& Pandita, S, Chat-Bot for College Management System Using AI. International Research Journal of Engineering and Technology, 2017

[5] Başgöze, P, Effects of Brand Credibility on Technology Acceptance Model: Adaption of the Model to the Purchase Intention, International Journal of Humanities and Social Science, Vol. 2 No. 20 [Special Issue - October 2012], pp. 792-798.

[6] Carlos Martins Rodrigues Pinho, J., \& Soares, A. M, Examining the technology acceptance model in the adoption of social networks. Journal of Research in Interactive Marketing, 5(2/3), 2011, pp 116-129. doi:10.1108/17505931111187767

[7] Doğan, İ, The application of artificial intelligence in new age of marketing An analysis on AI mobile banking apps (Doctoral dissertation, İstanbul Bilgi Üniversitesi), 2018

[8] Dole, A., Sansare, H., Harekar, R., \& Athalye, S, Intelligent Chat Bot for Banking System. International Journal of Emerging Trends \& Technology in Computer Science, 4(5), 2015, pp 49-51.

[9] Eeuwen, M. V, Mobile conversational commerce: messenger chatbots as the next interface between businesses and consumers (Master's thesis, University of Twente), 2017

[10] Hung SY, Chang CM, Kuo SR, User acceptance of mobile e-government services: An empirical study. Government Information Quarterly, 30(1): 2013, pp 33-44.

[11] Jonsson, S., \& Bredmar, J, Chatbot-Magic in a box?: A study of a chatbot in a Swedish bank, 2018

[12] Kim, S., Goh, J., \& Jun, S, The Use of Voice Input to Induce Human Communication with Banking Chatbots. In Companion of the 2018 ACM/IEEE International Conference on Human-Robot Interaction ACM, 2018, (pp. 151-152).

[13] Koul, S., \& Eydgahi, A, Utilizing Technology Acceptance Model (TAM) for driverless car technology. Journal of Technology Management \& Innovation, 13(4), 2018, pp 37-46. doi: https://doi.org/10.4067/S0718-27242018000400037

[14] Lai, P. C, The literature review of technology adoption models and theories for the novelty technology. JISTEM-Journal of Information Systems and Technology Management, 14(1), 2017, pp 21-38.

[15] L. Chandra Sekaran, Dr. S. Balasubramanian, Website Based Patent Information Searching Mechanism.International Journal of Computer Engineering \& Technology (IJCET) .Volume:1, Issue: 2, 2011, Pages: 180-191.

[16] Lau, T., \& Leimer, B, The era of connectedness: How AI will help deliver the future of banking. Journal of Digital Banking, 3(3), 2019, pp 215-231.

[17] Letheren, K., \& Dootson, P, Banking with a chatbot: A Battle between convenience and security. The Conversation, 2017

[18] Lorenzo, C. M., Lezcano, L., \& Alonso, S. S, Language Learning in Educational Virtual Worlds-a TAM Based Assessment. J. UCS, 19(11), 2013, pp 1615-1637.

[19] Lu, Y., T. Zhou and B. Wang, "Exploring Chinese users' acceptance of instant messaging using the theory of planned behaviour, the technology acceptance model, and the flow theory," Computers in Human Behaviour, Vol.25, No.1: 29-39, 2009.

[20] Okuda, T., \& Shoda, S, AI-based Chatbot Service for Financial Industry. Fujitsu Scientific and Technical Journal, 54(2), 2018, pp 4-8.

[21] Rauniar, R., Rawski, G., Yang, J., \& Johnson, B, Technology acceptance model (TAM) and social media usage: an empirical study on Facebook. Journal of Enterprise Information Management, 27(1), 2014, pp 6-30. doi:10.1108/jeim-04-2012-0011

[22] Rega, F. G, The bank of the future, the future of banking-An empirical analysis of European banks. Available at SSRN 3071742, 2017

[23] Sarstedt, Marko \& Ringle, Christian \& F. Hair, Joe, Partial Least Squares Structural Equation Modelling. 10.1007/978-3-319-05542-8_15-1, 2017 
[24] Shah, K. B., Shetty, M. S., Shah, D. P., \& Pamnani, R, Approaches towards Building a Banking Assistant. International Journal of Computer Applications, 166(11), 2017

[25] Smith, T. J., \& Nichols, T, Understanding the millennial generation. The Journal of Business Diversity, 15(1), 39, 2015

[26] Trivedi, J, Examining the Customer Experience of Using Banking Chatbots and Its Impact on Brand Love: The Moderating Role of Perceived Risk. Journal of Internet Commerce, 2019, pp $1-21$.

[27] T.Vijayakumar, Dr. R. Velu, Customer Relationship Management in Indian Retail Banking Industry, International Journal of Management (IJM), Volume 2, Number 1, Dec - Jan (2011), pp. 41-51

[28] Venkatesh, V., \& Bala, H, Technology acceptance model 3 and a research agenda on interventions. Decision sciences, 39(2), 2008, pp 273-315.

[29] Y Madan Reddy, Chandrasekhara Reddy T and P Dayaker, 2017. To Dialogue with Chatbot Using Machine Learning.International Journal of Mechanical Engineering and Technology (IJMET).Volume:8, Issue: 6, Pages: 729-739.

[30] Vieira, A., \& Sehgal, A, How banks can better serve their customers through artificial techniques. In Digital Marketplaces Unleashed Springer, Berlin, Heidelberg, 2018, (pp. 311326). 